\title{
Could be efficient management a solution for the success against Covid-19
}

\author{
Nicu-Pantelimon Rotaru, ${ }^{1, *}$, Nicolae Tașcă ${ }^{2}$, and Eduard Edelhauser $^{3}$ \\ ${ }^{1}$ University of Petrosani, 332003 Petrosani, Romania \\ ${ }^{2}$ University of Petrosani, 332003 Petrosani, Romania \\ ${ }^{3} \mathrm{Head}$ of Management and Industrial Engineering Department, University of Petrosani, 332003 \\ Petrosani, Romania
}

\begin{abstract}
Globally, the last 15 months have put health systems under unprecedented pressure during the last century, facing significant challenges in the management of organizations, patient care and the protection of medical staff, and the time to respond to the needs of communities. The context created by the SARS-CoV-2 pandemic shows us how important the functionality of a health system is, how manages could prevent the spread of the virus, how the number of tests or vaccinations could stop the spread of the virus. It is also important to provide access to health services for as many patients as possible, especially for those in vulnerable categories, but also to succeed in ensuring maximum safety conditions for specialized personnel (doctors, nurses, paramedics, ambulance drivers, pharmacists etc.). The authors considered that the essential features of each health system, in the analysis of how they responded to the challenges of the SARSCoV-2 (or COVID-19) pandemic, must be analyzed from the perspective of the medical act, its financing, and also from the use of modern technologies and resilience. Synthesis was made between the results of the 4 official studies presented by the Commonwealth Fund, Health Consumer Powerhouse, Bloomberg and U.S. This information, put by the authors in a comparative analysis with the updated data of the World Health Organization, constantly highlighted several health systems that had an effective management in the fight against the Covid-19 pandemic.
\end{abstract}

\section{Introduction}

The context created by the SARS-CoV-2 pandemic shows us how important the functionality of a health system is, how it manages to control the spread of the virus, to perform as many tests as possible, to provide access to health services for as many greater number of patients, especially for those in vulnerable categories, but also to succeed in ensuring maximum safety conditions for specialized staff (doctors, nurses, paramedics, ambulance drivers, pharmacists, etc.). For example, although there are two neighboring regions, statistics showed at the end

\footnotetext{
*Corresponding author: nicu.p.rotaru@gmail.com
} 
of March that in the Lombardy region, of the total COVID-19 infections, $14.3 \%$ were among health workers, as opposed to the Veneto region for which percentage was $4.4 \%$ [1].

Moreover, it is necessary to observe how health systems manage to ensure patients' access to regular services, but especially to emergencies, to specialized interventions. In this paper, the authors aimed to analyze the ways or even strategies of health systems considered to be the best, in the concrete conditions of a pandemic that has spread with astonishing speed. We noted the health systems that applied the best management of the health crisis during the present pandemic, according to objective criteria and official data.

\section{Theoretical Framework regarding the Health systems}

Health systems are organized in various ways, the authors presenting the classifications of Rothgang and Wendt, respectively European Health Systems, as guidelines in the paper. The deductive model developed by Rothgang and Wendt [2] presents 27 possible combinations, considering three functional processes: service provision, financing and regulation. According to this classification of health systems worldwide, there are ideal typologies, such as: National Health Service (State-state-state), Social Health System (Societal-societalsocietal), Private Health System (Private-private- private). The plausible number of types of health systems is reduced to 10, as in Figure 1.

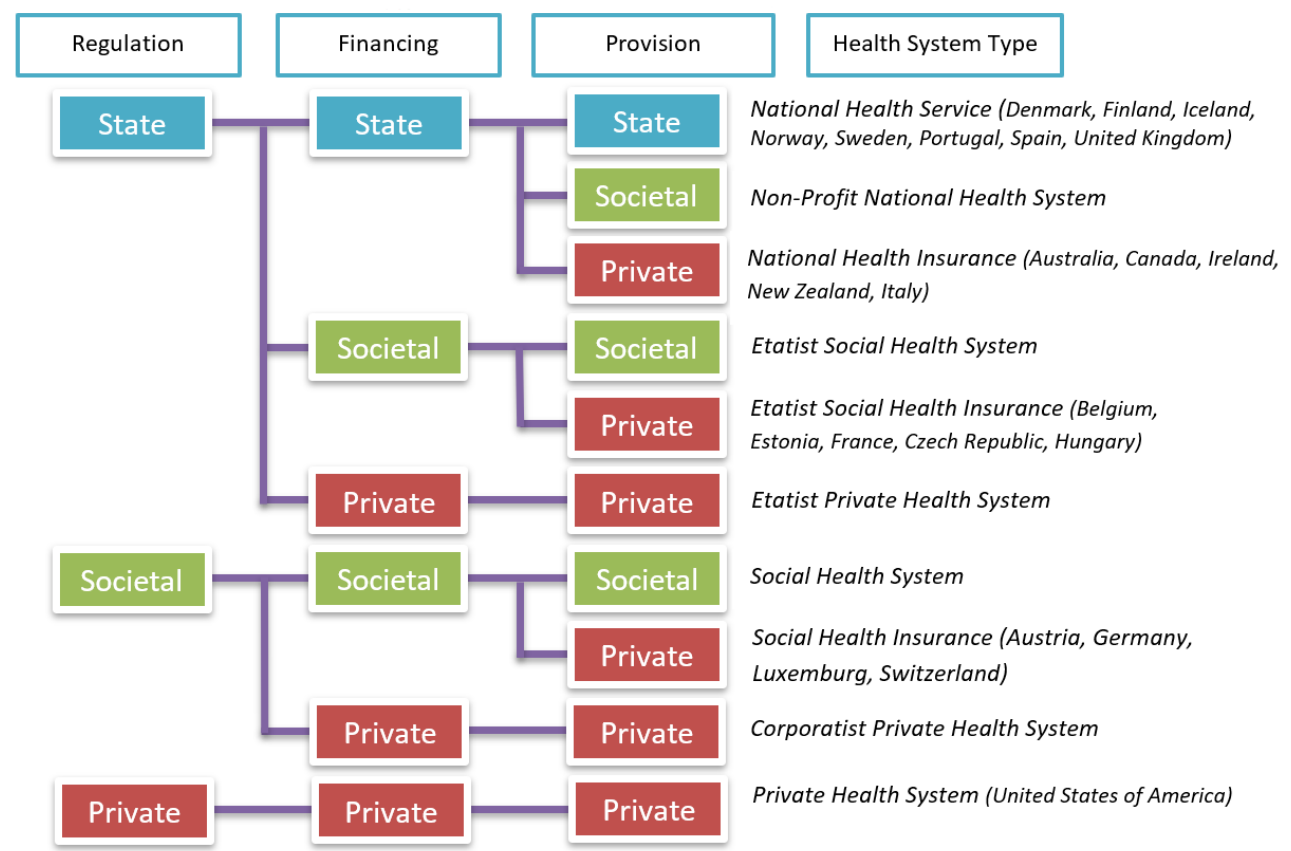

Fig.1 Plausible healthcare system types [2]

According to the way of financing, a classification of European health systems [3] distinguishes 3 types: Bismarck, Semashko and Beveridge (Table 1).

The Bismark model / Social health insurance system originates from German legislation, with features such as: mandatory contributions paid by both employee and employer, the principle of universal coverage (by the insurance company), the possibility of choosing the family doctor, the institutions that manage insurance funds to be non-profit. 
The Semashko model / Centralized state system is guided by: state funding, state control, health services are state-owned, staff with official status, equal access of the population to health services.

The Beveridge / National Health System model, of British origin, is characterized by: mandatory income taxes, facilitating a high degree of social equity, the state is the administrator of the health system, outpatient services are provided by staff paid by the state, etc.

Table 1. European health systems [3]

\begin{tabular}{|c|c|c|c|}
\hline \multicolumn{4}{|c|}{ Healthcare systems in Europe } \\
\hline Old systems & Systems from Worl & War II to the present & New systems \\
\hline $\begin{array}{l}\text { Social Security } \\
\text { System (Bismarck) } \\
\text { Germany, } 1893\end{array}$ & $\begin{array}{l}\text { Tax - funded system } \\
\text { (Beveridge) } \\
\text { England, } 1944\end{array}$ & $\begin{array}{l}\text { Reformed systems } \\
\text { that combine } \\
\text { elements from } \\
\text { Bismarck and } \\
\text { Beveridge }\end{array}$ & $\begin{array}{l}\text { Semashko- } \\
\text { Bismarck }\end{array}$ \\
\hline $\begin{array}{l}\text { Austria } \\
\text { Belgium } \\
\text { Israel } \\
\text { Luxembourg } \\
\text { Turkey } \\
\text { France } \\
\text { Netherlands } \\
\text { Switzerland } \\
\text { Romania }\end{array}$ & $\begin{array}{l}\text { Denmark } \\
\text { Iceland } \\
\text { Norway } \\
\text { Finland } \\
\text { Sweden }\end{array}$ & $\begin{array}{l}\text { Greece } \\
\text { Italy } \\
\text { Spain } \\
\text { Portugal }\end{array}$ & $\begin{array}{l}\text { Albania } \\
\text { Bulgaria } \\
\text { Latvia } \\
\text { Lithuania } \\
\text { Poland } \\
\text { Russia } \\
\text { Slovakia } \\
\text { Slovenia } \\
\text { Hungary } \\
\text { Croatia } \\
\text { Czech Republic }\end{array}$ \\
\hline
\end{tabular}

Presenting these two models, the authors intended to highlight that although there are classified health systems with common features, their effectiveness in controlling the health crisis was different. Although structurally some health systems are similar, there are particular factors that cause them to react differently to the crisis, such as: economic, social, cultural, population size, geographical positioning and / or political.

\section{A worldwide analyse of the public health crisis management in different systems}

The authors made a synthesis of 4 official studies conducted before the outbreak of the Covid19 pandemic, in the period 2017-2020, led by the Commonwealth Fund, Health Consumer Powerhouse, Bloomberg and U.S. News, also consulting an older WHO study [4]. Then, we carried out a comparative analysis between data of the above-mentioned studies and realtime statistics on the evolution of Covid-19, recorded 12 months after the outbreak of the pandemic. The statistical processing of the data was performed with Microsoft Excel, the collection of data provided by the World Health Organization and Worldomers being done in two stages, in December 2020, respectively in April 2021. The main indicators considered in the analysis and interpretation of the data were: positive cases, deaths, testing, vaccinations, total population or GDP. The data obtained from this comparative analysis present the health systems with the most efficient management in the face of the Covid-19 pandemic, depending on: the control of the spread of the virus, the number of deaths, the testing capacity or the vaccination capacity. 


\subsection{Study 1 - Commonwealth Fund}

In the study conducted by the Commonwealth Fund [5], which we will briefly call "Mirror, Mirror 2017", the performance of health systems in Australia, Canada, France, Germany, New Zealand, Norway, the Netherlands, Sweden, Switzerland, United Kingdom and United States was evaluated based on 72 indicators. Indicators such as safety, waiting times, administrative organization or equal access to healthcare corresponded to the following five areas: the care process, access, administrative efficiency, equity and healthcare outcomes. Data from surveys conducted by the Commonwealth Fund on patients and doctors were taken into account, as well as selected measurements from the Organization for Economic Co-operation and Development (OECD), the World Health Organization (WHO) and the European Observatory on Health Systems and Policies. The study aimed to capture the effectiveness of healthcare in the United States, with the results placing it last, suggesting that it should look at other countries' systems to increase the performance of its own health care system and make it accessible to all citizens.

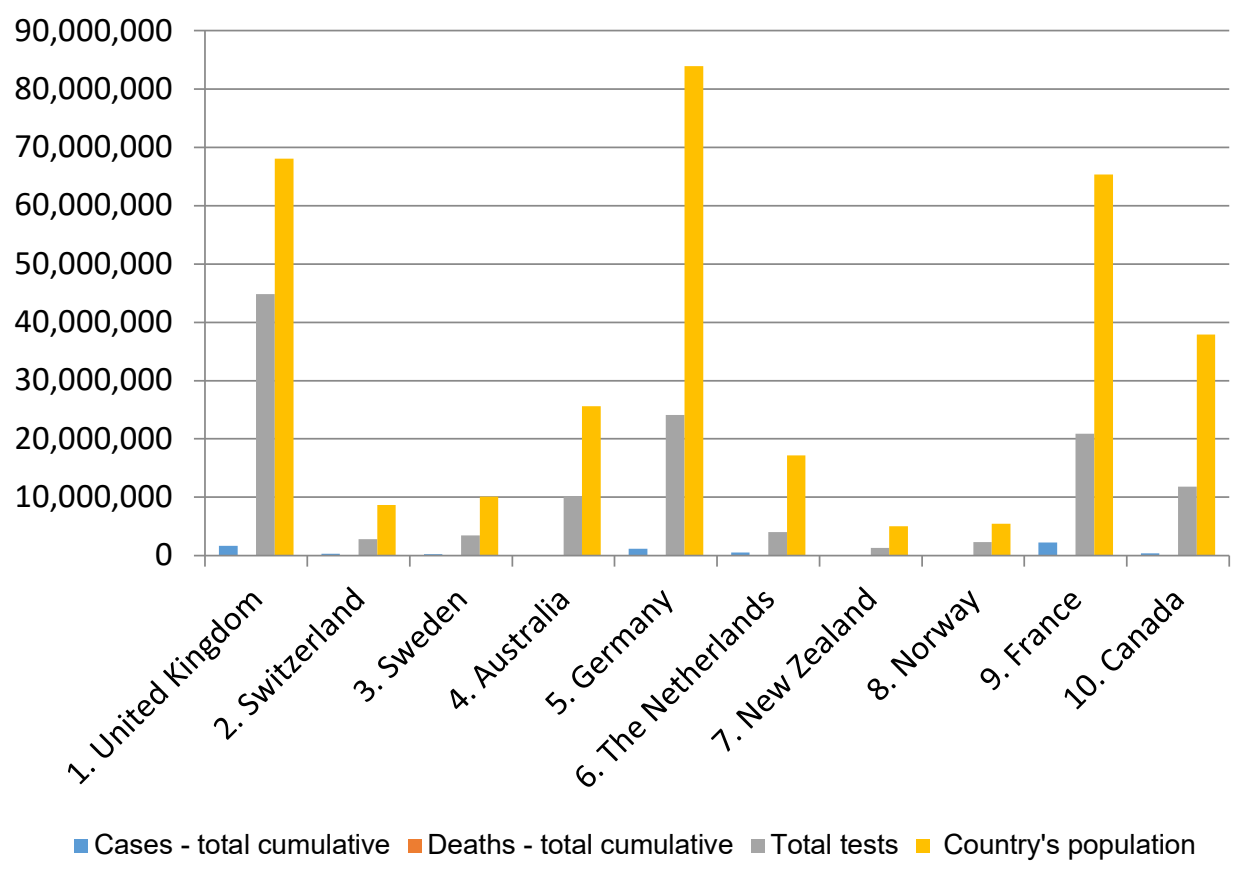

Fig.2 Ranking according to the Mirror Study, Mirror 2017 - Commonwealth Fund, correlated with data taken on December 5, 2020, 15:02 CET [6], [7]

The cumulative total of SARS-CoV-2 cases on 5 December 2020 (15:02 CET), in the order of the ranking presented by the Commonwealth Fund, is as follows: 1,690,436; 343,$101 ; 278,912 ; 27,949 ; 1,153,555 ; 543,264 ; 1,722 ; 37,371 ; 2,228,980 ; 396,270$, and the United States with $13,978,171$ cases, representing $21.50 \%$ of the total of $65,007,974$ worldwide. People of colour represent $13 \%$ of the U.S. population, but account for $20 \%$ of Covid-19 cases and more than $22 \%$ of Covid-19 deaths as of July 22, 2020. Hispanics, at $18 \%$ of the population, account for nearly $33 \%$ of new cases at national level [8].

Less than $1.00 \%$ of infected people in the total population of each country recorded New Zealand $(0.03 \%)$, Australia $(0.11 \%)$, Norway $(0.69 \%)$ and just over $1.00 \%$, Canada 
$(1.05 \%)$ and Germany $(1.35 \%)$, which shows that these countries have paid special attention to controlling the spread of the virus among their own citizens. The top 3 countries that have managed to treat their citizens as well as possible, showing that they have efficient health systems, with deaths below $1.50 \%$ of patients tested positive, are: Norway $(0.95 \%)$, Switzerland (1.40\%), New Zealand (1.45\%); followed quite closely by Germany $(1.60 \%)$ and Netherlands $(1.77 \%)$. Another important indicator that shows the efficiency of health systems is represented by the testing capacity of the population, the first 3 countries being: United Kingdom (65.86\%), United States of America (61.44\%) and Norway (43.22\%). All these data show us that the most efficient health system in the ranking made by the Commonwealth Fund is that of Norway with 2,350,736 tests applied to a population of 5,439,351 citizens, 37,371 infected people and 354 dead people. The United States has shown that it has a large capacity in terms of population testing, with over 200 million tests administered, but it has a number of almost 275 thousand deaths, which is about one-fifth of the total worldwide.

\subsection{Study 2 - Health Consumer Powerhouse}

A second study [9], the Euro Health Consumer Index (EHCI), conducted annually by the Swedish health policy think tank Health Consumer Powerhouse, classifies European health systems on the basis of 48 indicators, such as rights patients, waiting times for treatment, services provided to patients and prevention. The first 10 systems, out of the 35 studied, are represented graphically in Figure 7, with the specific data of the current pandemic, to see which of them responded best to this crisis.

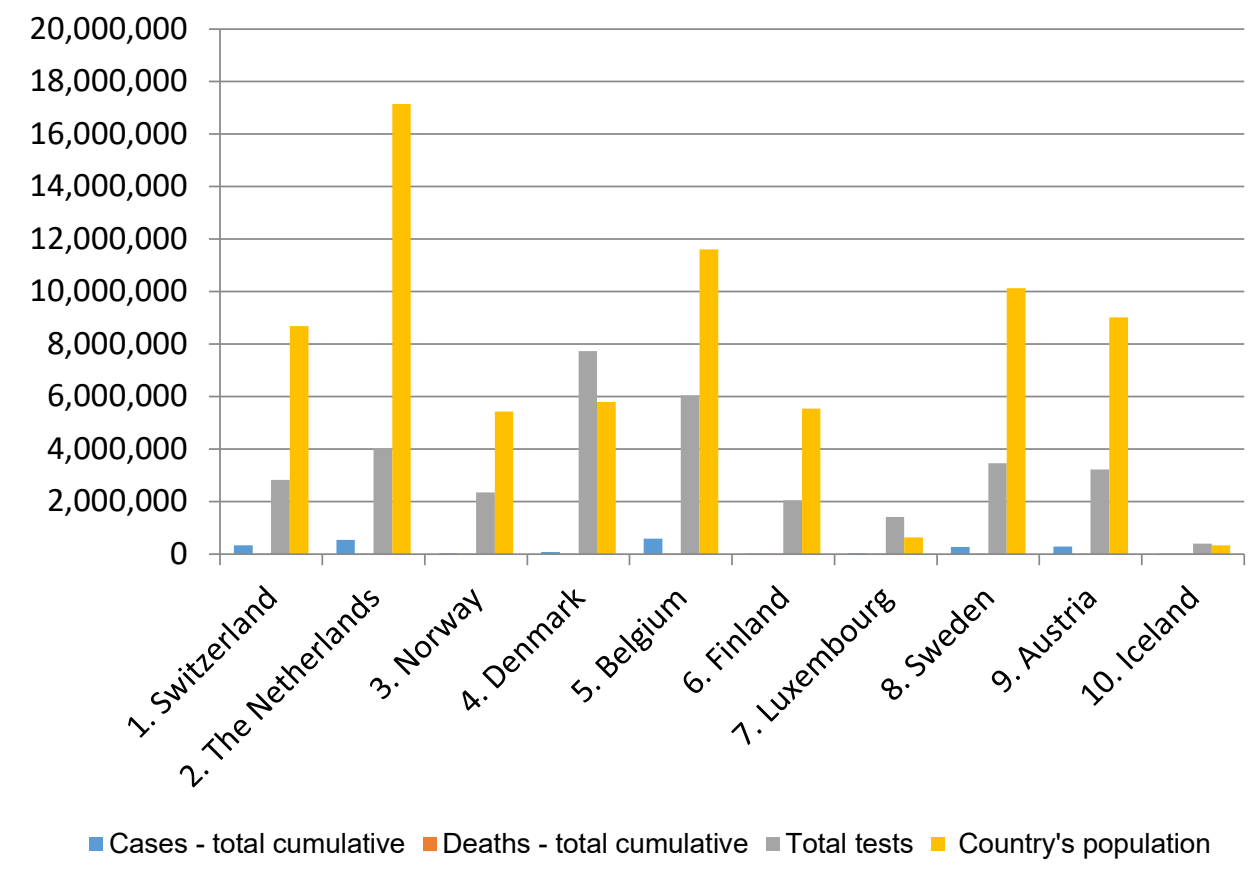

Fig.3 Ranking according to the Euro Health Consumer Index (EHCI) Study, correlated with data taken on December 5, 2020, 15:02 CET [6], [7]

The number of SARS-CoV-2 cases corresponding to the countries in this ranking is: Switzerland $(338,731)$, Netherlands $(543,264)$, Norway $(37,371)$, Denmark $(86,743)$, 
Belgium (587,439), Finland (26,758), Luxembourg (36,429), Sweden (278,912), Austria $(295,071)$ and Iceland $(5,462)$

With a population of just over 630 thousand inhabitants, Luxembourg has the highest infection rate $(5.78 \%)$, followed by Belgium (5.06\%) and Switzerland (3.90\%), Finland (0, $48 \%$ ) and Norway $(0.69 \%)$ being the countries that best controlled the spread of the virus among citizens. Luxembourg and Iceland proved to have a high testing capacity, with 2.25 tests / inhabitant, respectively 1.16 tests / inhabitant, however, having the advantage of a population not exceeding 1 million inhabitants cumulatively. Countries with a population of over 5 million, such as Denmark, Belgium or Norway, managed to apply tests in a proportion of $133.27 \%, 52.08 \%$ and $43.22 \%$ of the total population. Belgium had the weakest intervention, with a death rate of $2.92 \%$ among positive patients, followed by Sweden with $2.53 \%$. On the other hand, the health systems that best controlled the fight against the virus, with a death rate below $1.00 \%$, were those in Iceland $(0.40 \%)$, Luxembourg $(0.93 \%)$ and Norway $(0.95 \%)$.

Considering the number of infected people and the number of deaths recorded, as well as the testing capacity in relation to the total population, it can be said that the Norwegian health system was the most efficient in this ranking as well.

\subsection{Study 3 - Bloomberg}

The third study analysed, Most Efficient Health Care 2018 [10], conducted by the financial, software, data and media company Bloomberg, measured the health systems of 56 countries around the world, taking into account indicators such as: life expectancy, the cost of healthcare as a percentage of GDP and the cost of healthcare per capita to classify the world's healthcare systems.

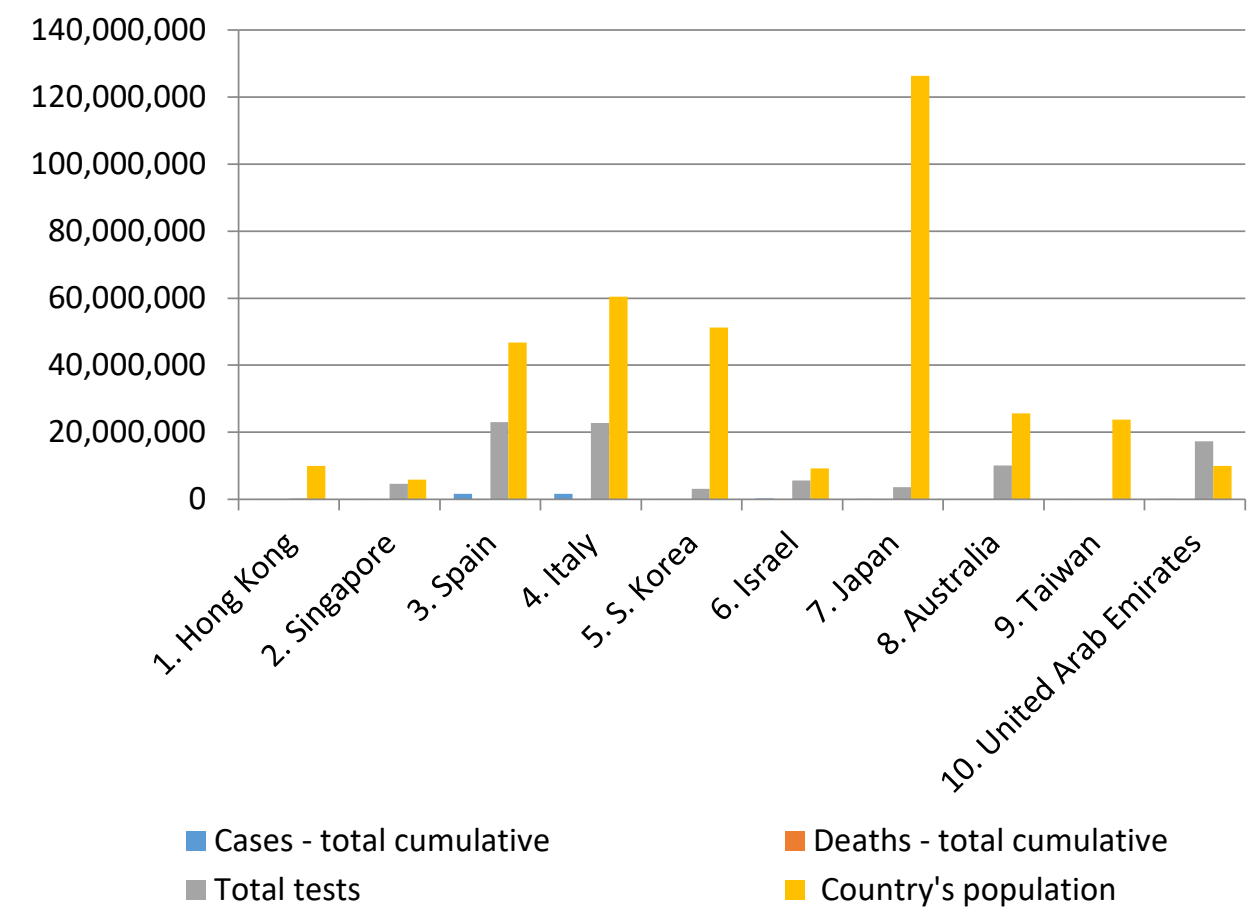

Fig.4 Ranking according to Bloomberg Study, Most Efficient Health Care 2018, correlated with data taken on December 5, 2020, 15:02 CET [6], [7] 
The number of people tested positive for Covid-19 for Bloomberg countries (Figure 4) is: Hong Kong $(6,803)$, Singapore $(58,242)$, Spain $(1,684,647)$, Italy $(1,688,939)$, South Korea $(36,915)$, Israel $(339,952)$, Japan $(157,674)$, Australia $(27,949)$, Taiwan $(693)$ and the United Arab Emirates $(174,062)$. Compared to its more than 50 million inhabitants, South Korea managed to control the spread of the virus, with a percentage of only $0.07 \%$ of the total population, in the same proportion as Hong Kong, Japan being another example in this regard with $0.12 \%$ of the over 126 million inhabitants. Israel (3.70\%), Spain (3.60\%) and Italy $(2.80 \%)$ are the countries with the most negative, with over 3.7 million positive cases.

The Singapore health system reacted very effectively to the pandemic, with a death rate of only $0.05 \%$ of all cases tested positive, and a very good percentage $(0.48 \%)$ also managed to control the spread of diseases. The health systems in Israel and the United Arab Emirates had a very good clinical response, with human losses of $0.34 \%$ and $0.85 \%$ of all infected people, respectively. The first three countries that managed a significant test of their own citizens were: United Arab Emirates (174.26\%), Singapore (79.37\%) and Israel (60.94\%). Singapore is the country in this ranking with a health system that controlled very effectively the spread of the virus, with a very high level of testing and, especially, of the healing of patients tested positive, with only 29 deaths recorded.

\subsection{Study 4 - U.S. News}

U.S. News [11] conducted a survey in early 2020 (Figure 5), ranking the best developed public health care systems in the world, with Europe holding its largest share.

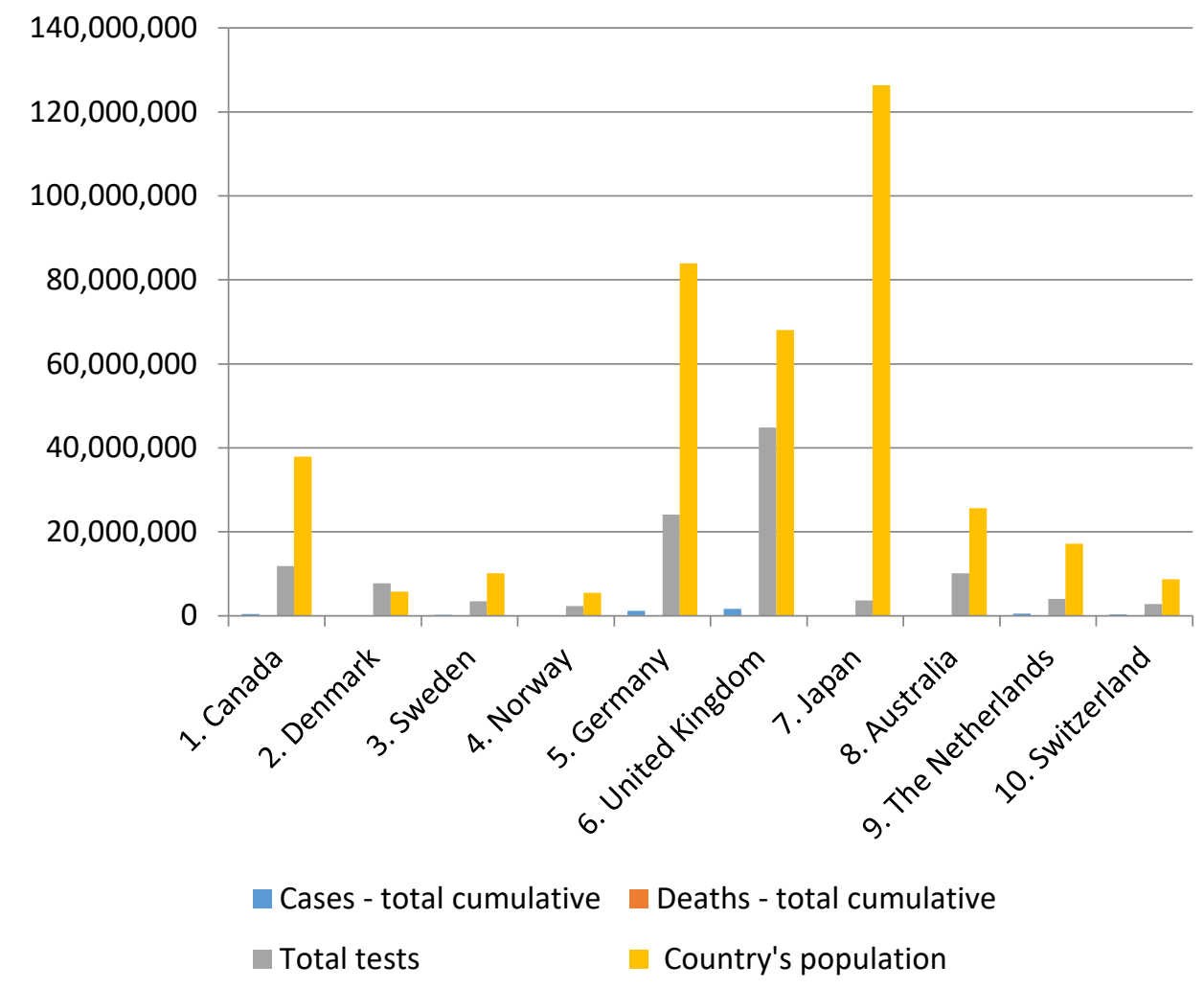

Fig.5 Ranking according to the U.S. News Study, correlated with data taken on December 5, 2020, 15:02 CET [6], [7] 
The data presented by the WHO place the health systems of Japan $(0.11 \%)$, Australia $(0.12 \%)$, and Norway $(0.69 \%)$ at the top of the ranking on controlling the spread of the epidemic. Norway, Denmark and Australia had the best control over patients infected with SARS-CoV-2, managing to keep the number of deaths below the threshold of 1,000, with the following absolute values: 354,867 and 908 deaths. Worldometer places Denmark at the forefront of the systems with the highest number of tests applied (133.27\%), followed by the United Kingdom with $65.86 \%$ and $43.22 \%$ of tests applied in relation to the total population. And this time Norway is noted for the effectiveness of the health system in the conditions of the Covid-19 pandemic.

\section{Results and Discussions}

The health systems from the 8 countries represented in Figure 6, selected from the four rankings studied, managed to keep the number of deaths below 1,000 people, at a considerable number of positive cases detected. Cumulatively, the number of deaths was 4,038 people, which represents $0.83 \%$ of the number of infected people, respectively $0.003 \%$ of the total population of the 8 countries. Between December 5, 2020 - April 5, 2021, two health systems among those previously ranked in the top of the best in the world were distinguished by a good control of the spread of the virus (Australia - 1,428 cases, Singapore - 2,312 cases), but more by providing medical care, each of them registering only 1 death. The European health system that stood out in the fight against the Covid-19 pandemic, the Norwegian one, registered 62,778 new cases in the last 4 months, but with a loss of human lives of only $0.51 \%$. In the 12 months since WHO declared the Covid-19 pandemic on March $11,2020,3030$ front-line health care workers have died, the youngest being 20 years old [12]. On April 7, 2021 (10:51 GMT), the health systems noted in December in the 4 studies mentioned, compared with the data provided in real time by WHO and Worldometers, present the following relative values regarding the positive cases in the total population of each countries: New Zealand (0.05\%), Australia (0.11\%), Japan (0.39\%), Singapore $(1.03 \%)$, Iceland (1.82\%), Norway (1.87\%), United Arab Emirates (4.75\%), Israel (9.08\%) and Luxembourg (9.88\%).

\section{- Under 1,000 deaths}

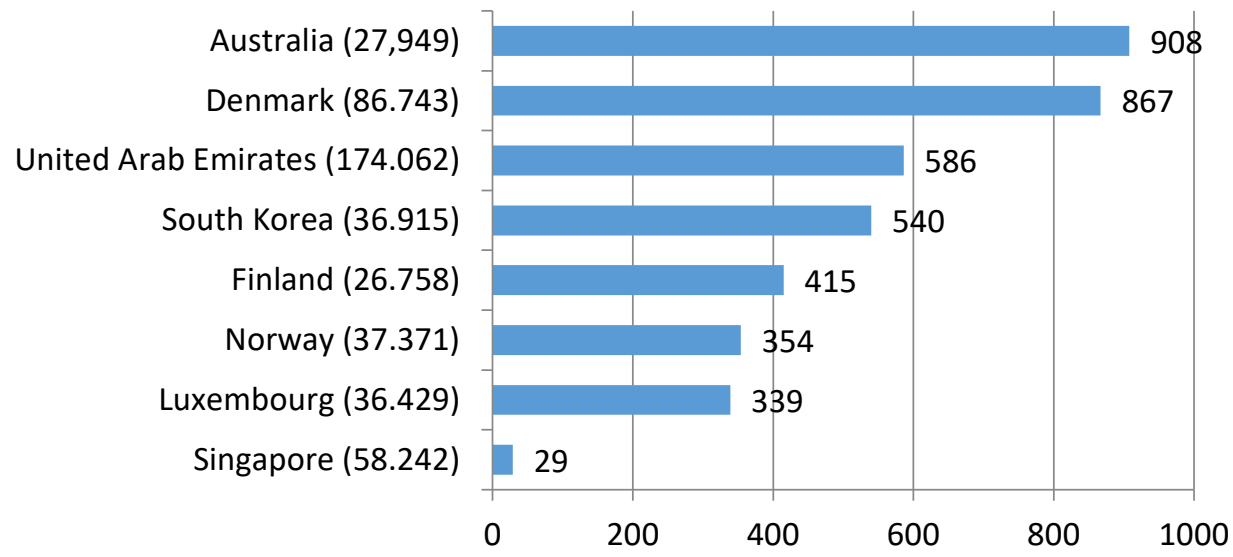

Fig.6 Health systems specified in the Commonwealth Fund, Health Consumer Powerhouse, Bloomberg and U.S. News rankings with deaths below 1,000 patients in over 25,000 positive tests, data taken on December 5, 2020, 15:02 CET [6], [7] 
Our World in Data (Figure 7), a statistical tool of the Oxford Martin School and the University of Oxford [13], presents the situation of sharing the total population that received at least one dose of vaccine: Israel (60.73\%), United Arab Emirates (35.19\%), Singapore (17.95\%), Iceland (14.73\%), Luxembourg (11.69\%), Norway (12.99\%), New Zeeland (1.08\%), Japan (0.76\%) and Australia (0.62\%).

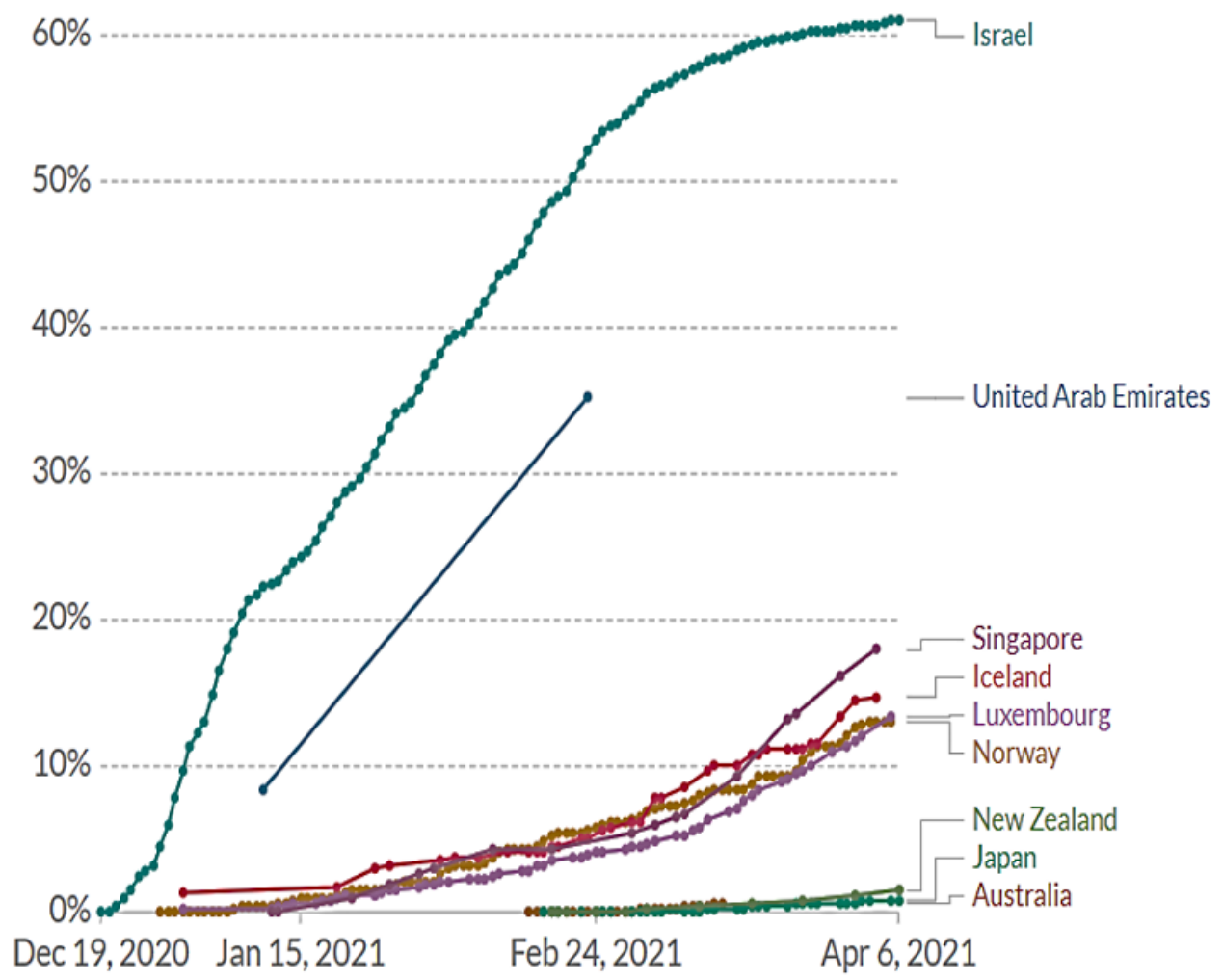

Fig.7 Share of people who received at least one dose of COVID-19 vaccine, data taken on April 7, 2021 (10:51 GMT) [13]

In general, a direct proportional relationship can be seen between the detected cases and the administration of Covid-19 vaccines. New Zealand, Japan and Australia had good control of the spread of the virus, respectively a low number of vaccinations, while at the other extreme, Israel, United Arab Emirates or Luxembourg, had a large number of positive cases but also vaccinations. A special case is Singapore, which although it had good control over the spread of the virus, paid special attention to positive cases with only 30 deaths, does not neglect the appearance of vaccination. There is also a directly proportional relationship between the management of the health crisis and the percentage given to the health sector in the GDP by each of the mentioned countries, Singapore being the exception this time as well (Figure 8): Japan (10.953\%), Norway (10.316\%), Australia (9.205\%), New Zeeland (9.02\%), Iceland $(8.343 \%)$, Israel (7.498\%), Luxembourg (5.258\%), Singapore (4.418\%) and United Arab Emirates (4.145\%). 


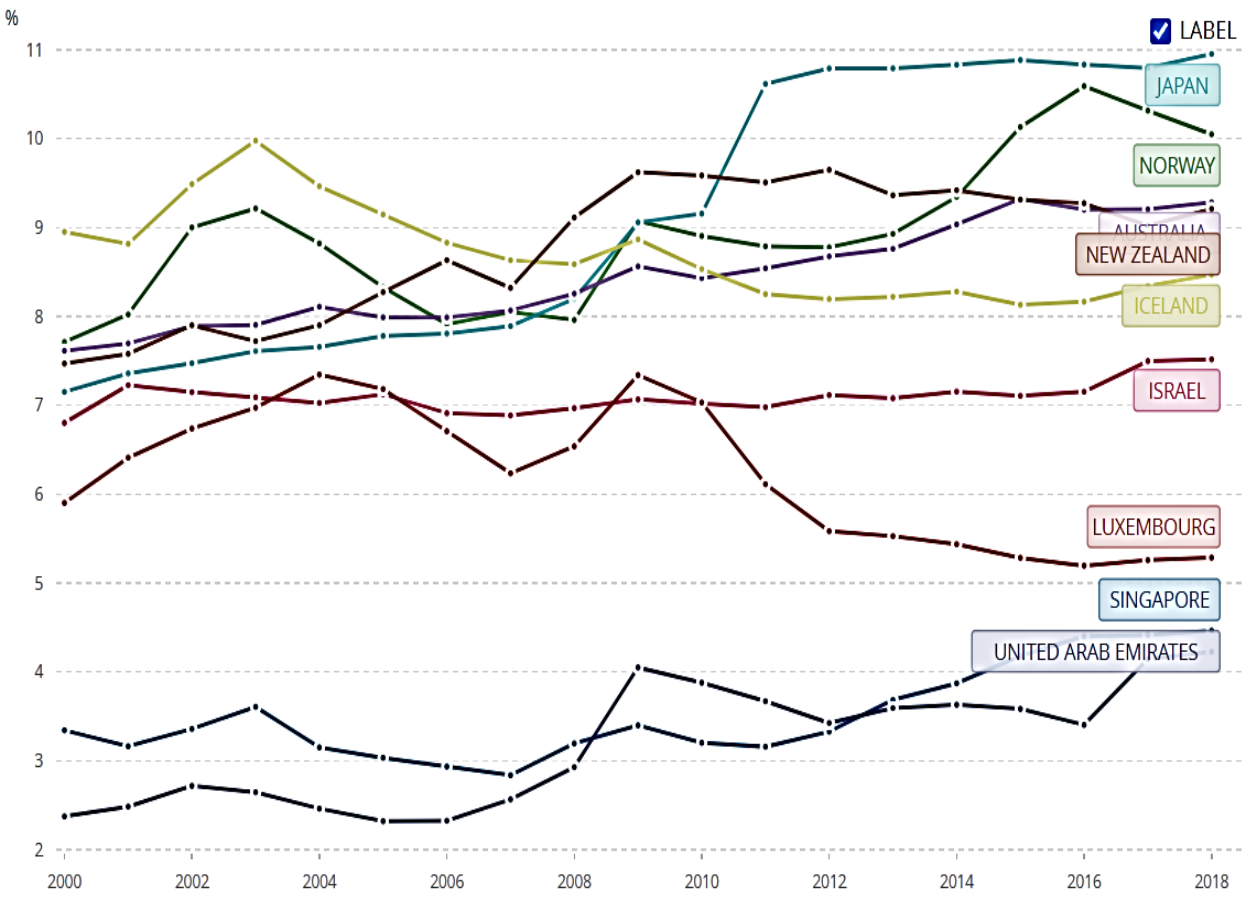

Fig.8 Current health expenditure (\% of GDP), data taken on April 7, 2021 (10:51 GMT) [14]

As the health system in Singapore has stood out at all levels in the management of the crisis caused by the Covid-19 pandemic, the authors consider it imperative to present the organization and institutions that facilitate the public health approach. The funding framework for health care in Singapore is multipayer, a system known as $3 \mathrm{M}$, so treatment can be provided through many schemes and payers, even overlapping [15]: MediShield Life - universal basic health care insurance, mandatory for citizens and permanent residents, offers lifelong protection against high hospital bills and expensive outpatient treatments; MediSave - national system of medical savings, helps cover out-of-pocket payments, mandatory for all working citizens and permanent residents, can be used to pay for the health care expenses of family members; MediFund - the government safety net for citizens who cannot cover their expenses out of pocket. The Ministry of Health has centralized certain functions to prevent fragmentation and to encourage economies of scale. National organizations with important functions include the following: MOH Holdings, The Agency for Integrated Care, The Agency for Care Effectiveness (Singapore's national health technology assessment agency), The Health Sciences Authority, The Health Promotion Board, The Central Provident Fund Board, which administers the MediSave and MediShield Life schemes on behalf of the Ministry of Health.

The authors consider that if the results obtained by the mentioned health systems depended on their fast or proactive reaction, on a very good health infrastructure or on an adequate financing, the resilience will be the object of a common effort of all the health systems. Obviously, these health systems can be considered examples of good practice that it is imperative to apply in other systems, taking into account the particularities of each. Moreover, a rethinking of the health strategy common to all states is needed to face a new global challenge. 


\section{Conclusion}

In the conditions of a pandemic that spread at a very fast pace, the authors highlighted the most important health systems in the world, designated according to well-defined criteria in very rigorous studies. Up-to-date data on the effects of the Covid-19 pandemic show us the perspective in which each of the health systems analyzed managed the crisis, focusing on one or more of the following aspects: controlling the spread of the virus (New Zealand - $0.05 \%$ ), Australia $-0.11 \%$, Japan $-0.39 \%$, Singapore $-1.03 \%$ ), saving as many human lives as possible (Singapore - 0.05\%, Emirates - 0.32\%, Iceland - 0.46\%, Israel - 0.75\%, New Zealand $1.03 \%$ ), testing capacity (United Arab Emirates - 391\%, Luxembourg - 388\%, Iceland $161 \%$, Singapore $-149 \%$, Israel - 148\%) or vaccination population (Israel - 61\%, United Arab Emirates - 35\%, Singapore - 18\%, Iceland - 15\%, Norway - 13\%). The main objective of the health systems was to minimize the number of casualties, so that the most efficient management of emergency medical services was provided by: New Zealand (26 deaths), Iceland (29), Singapore (30), Norway (677), Luxembourg (761) and Australia (909). Singapore and Australia stand out with only one patient dead in the last 4 months.

In the opinion of the authors, Singapore has developed the best health management in the face of the Covid-19 pandemic, based on the following framework: the expertise gained in 2003 in the fight against the Severe Acute Respiratory Syndrome (SARS), with effects on both individual and social consciousness; increasing the capacity of the intensive care units; training doctors in infectious diseases; conducting national exercises in order to raise public awareness and test the response capacity of the health system.

By allocating $4.4 \%$ of GDP to health expediture, Singapore has managed to control the fight against the new coronavirus based on a highly structured health system, as well as an attitude of mutual trust between politicians, scientists and citizens. One of the great strengths in the fight against the Covid-19 pandemic of the Singapore health system is that the population is open to digital innovations, the TraceTogether application being a tool to control the spread of the virus used exclusively within the country by over 4.7 million users.

The authors emphasize that the success of various health systems in the fight against the Covid-19 pandemic depended on several cumulative factors, such as: rapid reaction and coordination of institutions, training of specialists, medical infrastructure, management at central level and at hospital unit level, geographical positioning, population size, information and awareness, social discipline or use of digital technologies.

The authors note that in addition to the criteria taken into account in establishing the rankings with the best performing health systems mentioned in this paper, the effectiveness in the face of the present pandemic and, subsequently, that of resilience could be added. One of the major roles of this pandemic is to change the paradigm of healthcare management.

\section{References}

1. D. Kringos, F. Carinci, E. Barbazza, et al. Managing COVID-19 within and across health systems: why we need performance intelligence to coordinate a global response. Health Res Policy Sys 18, 80 (2020). https://doi.org/10.1186/s12961020-00593-x [Accessed on 10.11.2020]

2. K. Böhm, A. Schmid, R. Götze, C. Landwehr, H. Rothgang. Classifying OECD Healthcare Systems: A Deductive Approach. TranState Working Papers No. 165. Bremen. SFB 597 (2012). Available at: https://www.researchgate.net/publication/266483679 Classifying_OECD_Health care_Systems A Deductive_Approach. [Accessed on 11.11.2020]

3. A. Miron. O radiografie a sistemului de sănătate din România. Revista de științe politice Polis. Volum VIII, Nr. 1 (27), Serie nouă, decembrie 2019-februarie 2020. 
Available at: https://revistapolis.ro/o-radiografie-a-sistemului-de-sanatate-dinromania/. [Accessed on 13.11.2020]

4. A. Tandon, C. J. L. Murray, J. A. Lauer, D. B. Evans. Measuring Overall Health System Performance for 191 Countries. Available at: https://www.who.int/healthinfo/paper30.pdf. [Accessed on 15.11.2020]

5. E. C. Schneider, D. O. Sarnak, D. Squires, A. Shah, M. M. Doty. Mirror, Mirror 2017: International Comparison Reflects Flaws and Opportunities for Better U.S. Health Care. The Commonwealth Fund (2017). Available at: https://www.commonwealthfund.org/publications/fund-reports/2017/jul/mirrormirror-2017-international-comparison-reflects-flaws-and. [Accessed on 15.11.2020]

6. World Health Organisation, WHO Coronavirus (COVID-19) Dashboard. Available at: https://covid19.who.int/table. [Accessed on 05.12.2020, 07.04.2021]

7. Reported Cases and Deaths by Country or Territory. Available at: https://www.worldometers.info/coronavirus/?. [Accessed on 05.12.2020, 07.04.2021]

8. D. Blumenthal, E. Fowler, M. Abrams, S. R. Collins. Implications for the Health Care System. N Engl J Med; 383:1483-1488 (2020). DOI: 10.1056/NEJMsb2021088. Available at: https://www.nejm.org/doi/full/10.1056/nejmsb2021088. [Accessed on 18.11.2020]

9. A. Björnberg, A.Y. Phang. Euro Health Consumer Index 2018 Report. Health Consumer Powerhouse Ltd., ISBN 978-91-980687-5-7 (2019). Available at: https://healthpowerhouse.com/media/EHCI-2018/EHCI-2018-report.pdf. [Accessed on 19.11.2020]

10. L. Milller,W. Lu. These Are the Economies With the Most (and Least) Efficient Health Care. Bloomberg L.P. (2018). Available at: https://www.bloombergquint.com/global-economics/u-s-near-bottom-of-healthindex-hong-kong-and-singapore-at-top. [Accessed on 19.11.2020]

11. S. Radu. Countries With the Most Well-Developed Public Health Care Systems (2020). Available at: https://www.usnews.com/news/bestcountries/slideshows/countries-with-the-most-well-developed-public-health-caresystem?slide $=12$. [Accessed on 15.11.2020]

12. E. Kincaid. One Year Into the Pandemic, More Than 3000 Healthcare Workers Have Died of COVID-19 - Medscape (2021). Available at: https://www.medscape.com/viewarticle/947304. [Accessed on 08.04.2021]

13. H. Ritchie, E. Ortiz-Ospina, D. Beltekian, E. Mathieu, J. Hasell, B. Macdonald, C. Giattino, C. Appel, M. Roser. Statistics and Research. Coronavirus (COVID-19) Vaccinations. Available at: https://ourworldindata.org/covid-vaccinations [Accessed on 07.04.2021]

14. The World Bank. Current health expenditure (\% of GDP) - Singapore, Norway, United Arab Emirates, Israel, Japan, Australia, Iceland, Luxembourg, New Zealand. Available at: https://data.worldbank.org/indicator/SH.XPD.CHEX.GD.ZS?end=2018\&location $\underline{\mathrm{s}=\mathrm{SG}-\mathrm{NO}-\mathrm{AE}-\mathrm{IL}-J P-A U-I S-L U-N Z \& \text { start=2000\&view=chart } \quad[\text { Accessed on }}$ 07.04.2021]

15. L. C. Earn. International Health Care System Profiles - Singapore (2020). Available at: https://www.commonwealthfund.org/international-health-policycenter/countries/singapore [Accessed on 07.04.2021] 